\title{
West African Museums Project funded by Ford Foundation
}

This project is designed to contribute to the preservation of West Africa's cultural heritage. It seeks to improve and develop museological resources and structures in the region on a basis of positive collaboration between Anglophone and Francophone countries. A project office has been opened in Abidjan, Ivory Coast (01 B.P. 1658 Abidjan 01) where its Director, Dr Philip Ravenhill, a Senior Fellow of the Institute, is based. The project will run initially for two years from October 1982 and its budget is $\$ 285,000$.

Priority will be given to strengthening new and struggling museums taking advantage of the experience of the better established and more developed museums in West Africa. Special attention will be given to developing the most appropriate methods, on a basis of regional cooperation, for ensuring that the contents of museums are properly preserved against deterioration and safeguarded against theft and illicit export abroad.

This project is intended to engage the cooperation of both public and private museums, in particular the growing number of university museums, with the International Council on Museums, Paris, under its Secretary-General, Luis Monreal.

The project's specific aims are:

1. Improvement of present systems of making inventories and cataloguing existing collections and development of systems of exchange between museums throughout the region.

2. The promotion of adequate systems of documentation of museum collections, in particular through the establishment of phototeques and reference libraries.

3. The exchange of information on technical problems of conservation, preservation and storage, and of museum management in general between museums within West Africa, and the dissemination of relevant experience of museum systems outside the area.

4. Exploration of ways in which museums can improve their present programmes of acquisition and field research.

5. Exchange of experience concerning publicity and the dissemination of information about museums and their contents.

6. Assessment of museological training programmes used by museums both within the region and abroad with a view to establishing more appropriate programmes.

The means of attaining these goals will be two-fold:

a) Through workshops, symposia and the establishment of networks for the exchange of information among the existing museums of West Africa;

b) The establishment of pilot projects in selected museums in the region, concentrating initially on the following countries: Mali, Upper Volta, Benin (francophone); Nigeria, Liberia and Sierra Leone (anglophone); and Guinea-Bissau (lusophone). 